\title{
8
}

\section{A Curriculum for teachers or for learning?}

\author{
Paul Nicholson
}

Deakin University, Australia

\begin{abstract}
What should the focus of an informatics curriculum be? The majority of existing courses mimic industrial or commercial practice and reflect a particular vision of teaching and learning. Humanistic and constructivist perspective's suggest that alternative course models can empower students to become independent learners capable of operating in the complexities of modern society. The implementation of such a curriculum focus would place enormous strains on teachers and schools. Is this approach worth pursuing? What are the advantages to learners and what are the costs to schools?
\end{abstract}

Keywords: curriculum policies, information technology, learner centred learning, pedagogy, philosophy

\section{INTRODUCTION}

As we approach the middle of the third decade of widespread computer use in schools, it is timely to reflect on the evolution of classroom pedagogy and curriculum practices and to review how the computer has changed the curriculum, the nature of teaching and learning and indeed schools themselves.

In the first decade, loosely $1970-80$, technocentric paradigms [1] of computer use drove the curriculum and dominated classroom practice. 
Limited hardware and software capabilities and transmissive models of teaching and learning dominated practice and much was expected of "drill and practice" software, particularly in mathematics. Computers were expected to redefine the role of the teacher and to bring about new efficiencies in schools. By the end of the decade, concerns were being raised about the lack of real improvement in the nature and quality of classroom teaching under these paradigms. Learner centred paradigms began to emerge [2], signalling the development of broader understandings of how computers might be used to facilitate learning across a range of disciplines. Concurrently, educators began to plan for the wide scale use of computers across the curriculum [3].

"Computers across the curriculum" may well have been the catch cry of the 1980's (the second decade) with computers being applied to most discipline areas. In this decade, a diverse range of paradigms of use existed concurrently. Many of these reflected technological improvements in hardware or software developments, but were still essentially based on the older technocentric paradigms. The emergence of "Information Technology" (IT) as an identifiable entity had a profound effect upon the curriculum with the implementation of courses related directly to business and commerce, or aligned to national imperatives. The imposed need to develop IT skills affected the curriculum much as the Sputnik affected American science education. Towards the end of the decade, the nature and role of IT was being seriously questioned, and educators began to adopt the learner-centred paradigms alluded to a decade before [4-8].

In the 1990's, computers are in wide-scale use in schools in most technologically advanced nations. The rationale for their ongoing place in the curriculum, their mode of use and their effectiveness in achieving their perceived goals forms the basis of the remainder of this paper.

\section{WHAT KIND OF CURRICULUM?}

What kind of informatics curriculum should we provide for our students? What vision of society, individuals and learning should it embody? Why? These key questions are often overlooked in the pragmatics of planning or imposing curriculum on schools and school systems, especially in the areas of computing and technology. I believe that the issue revolves around the perspective that schools adopt about what a curriculum should $d o$, and for whom. At one level many curriculum projects, for example the Australian National Curriculum project (in development), are about defining and classifying the scope of activities that students are exposed 
to. They are essentially planning documents for teachers and schools to use to ensure that their curriculum has satisfactory "breadth". While it includes information about student profiles (performance indicators), it is essentially an organisational model of curriculum development not all that different from those in the UK. In this paper I do not wish to debate the nature and content of such imposed curricula, even given their importance to schools, but rather to focus on two diametrically opposed curriculum models which could be (and are) used by schools in implementing an informatics curriculum.

\section{Technocentric curriculum models}

For most of this century, the dominant educational paradigm of western countries has been a technocentric one, delivering education in a Taylor-like mass production process [9]. This is particularly true in the classroom use of computers where there is a new emphasis on learning about technology, that is, computers, to be able to better meet the perceived needs of industry. In these models, the purpose of the information technology curriculum is typically to provide:

- some knowledge and understanding of computers and their technology;

- some knowledge and understanding of the impact of computers on society;

- some knowledge of computer applications and the use of a variety of contexts for them;

- the ability to use a few standard types of software;

- the ability to write some simple programs.

This type of curriculum is usually presented as a senior IT course, or at a lower level, as "computer awareness". In many cases there is little attempt to integrate the use of this computer knowledge into the mainstream curriculum; the computer remains a technological entity to be studied in an abstract way; interesting, relevant, but not in my subject. The current UK IT curriculum is a good example of this type of curriculum. Papert believes that the localisation of computers, that is, withdrawing them from classrooms into laboratories and the formalisation of their use in IT courses, is the major curriculum issue of this decade [10].

The relevance of these pragmatic curriculum models, and their frequently associated behaviourist models of teaching, learning, and assessment to the challenges of modern society are being increasingly questioned by academics and philosophers [11-13] who see alternative 
ways for individuals to participate in a society heavily reliant on information technology and rapid access to information.

The institutional response to criticisms of the traditional (technocentric) informatics curricula has been to develop more flexible instructional systems. A typical example is the "Ford Academy of Manufacturing Sciences" program which aims to provide students with a wider range of educational experiences within a business context. The focus however is still instructional and essentially reductionist; focusing on the future needs of industry by ensuring that students gain a wider range of specific business-related skills than they would have had previously.

Currently, many national educational policies implicitly or explicitly locate schools within what is now termed an "economic-rationalist" model in which schooling serves as preparation for participation in the industrial and economic spheres of society. The commercialisation and corporatisation of education by business is a major concern as schools increasingly struggle with the dichotomy between egalitarian models of education and funding sources based on sponsorship models and targeted marketing policies [14]. Implicit in this business relationship is the idea that schools will in some way embrace the goods, services or philosophy of the sponsor or provider. For example in the United States, both Apple Computer and IBM have initiated massive sponsorship of educational programs, ranging from single schools to whole school districts; for example the Electronic School District Project in Indiana [15]. In the overall context of American education, these sponsorships are trivial in that the system is large and robust enough to absorb them as interesting experiments or case studies. They do not, of themselves, become the mainstream however much the sponsor would like them to. In smaller or less well resourced countries, this is a real danger and it must be guarded against. Hawkridge's analysis [16] of the short-term political benefits to third-world countries of implementing "computers in education" should be kept firmly in mind here as corporate sponsorship usually provides ready access to technology without providing an underpinning pedagogical basis for its classroom use. There is also a distinct lack of concern, regardless of marketing rhetoric, with the quality of education that results, and often a desire to measure learning outcomes in a simplistic way that ignores the complexities of human learning.

The emergence of post-structuralist, post-modern curriculum theories and the demise of positivist paradigms provides a set of theoretical, analytical frameworks with which to deconstruct these older curriculum models. However whilst informing us about the real agenda behind these 
curricula, they do little to inform us about what might replace them. Fortunately, the last decade has seen an increased interest in the psychological foundations of learning, and of ways of using computational media to facilitate learning not teaching. The research in this area provides many useful guidelines about ways of using computers in schools that are different from the traditional IT focus, concentrating instead on ways to bring about quality learning. To implement these ideas though will require a major change to the nature and content of the school curriculum and classroom practice. The fundamental change is a shift from technocentric thinking about "using computers in the curriculum" to humanistic thinking about the same issues. The change is essentially a shift from "learning about the machine" to "using the machine in learning".

\section{A humanistic curriculum model}

"The computer should be like a pencil, not as an isolated class, but as a tool which empowers children with knowledge, thinking skills and problem solving alternatives" [17]. This is the fundamental tenet of humanistic computing. It represents an approach to education and learning which is essentially constructivist (or constructionist, in Papert's terminology) in nature and which is based on a substantial body of educational practice and psychological research. The constructivist model of learning is radically different from the more traditional models that predominate in schools. It has a focus on learning rather than on the use of technology. It provides schools with a key issue to discuss in planning their informatics curriculum - what are we trying to do with computers in schools, and why?

A curriculum based on constructivist guidelines should at least have a focus on:

- the student as the constructor of knowledge;

- independent and flexible pathways through traditional curriculum areas;

- an appreciation of the difficulties of "realistic assessment" as currently being debated in the literature;

- the use of computational media to facilitate learning.

While these sound like utopian items, and for many schools in many countries they are, there are a few schools actively involved in attempting to implement some or all of these items in their curriculum. The problem that they face is in identifying a suitable curriculum model. Perhaps the most widely understood, and best researched in this paradigm, is Papert's computational model [18]. In this model, computers act as personal 
knowledge tools in an environment in which students can engage with, and explore, their developing knowledge, using Logo as a programming tool. Some research has shown that Logo programming can produce marked conceptual change and alter the role of teacher and student in the construction and transmission of knowledge [19]. However, while Papert can display successful examples of his philosophy being implemented in schools, these generally occur only in special environments. For example both the Henigan school in Boston and Melbourne's Methodist Ladies' College (MLC) are both atypical schools in that the former is heavily supported by MIT and the latter by a large investment of private school funds. A key to MLC's successful adoption of a "Logo-like" curriculum focus has been an extensive, longitudinal program of staff development and assistance in the purchase of computers by staff. Additionally, MLC has shifted much of the cost of the innovation, approximately $\$ 2,000$ (AUD) per child, onto parents of new students, who are required to have access to an IBM compatible (386-SX or better) lap-top computer from grade 7 onwards. The junior school (pre grade seven) also uses lap-top computers in its curriculum and some parents have opted to buy them for their children's use, whilst others have leased them from the school. Other Australian schools have now adopted lap-top computers in their curriculum, but MLC is unique amongst these in having an informatics curriculum solidly based on a defined area of educational research.

In such a focused and well resourced school environment, it could be expected that the benefits of a Papert's (computational) environment would be obvious; with many of the students displaying significant programming skills and being able to apply them to all curriculum areas. While many MLC students can, and must, be advanced Logo programmers, much of their computer use is for word processing and there appears to be a reduction in emphasis on programming for knowledge construction in senior years. In many ways it appears as if the whole concept has become institutionalised, losing its fundamental "student as learner" focus to the incorporation of Logo into a more formally structured curriculum.

Can this essential focus be sustained in "normal" classrooms and average schools? The MLC experience has clearly shown the need for a huge investment in technology, in infrastructure and in staff development. This is not likely to be possible for an average Australian, American or British school system. Does this mean that Papert's model is unrealistic and that such an emphasis on individual computational skills is inappropriate? Can the model be successfully scaled down to individuals in individual classrooms? These are questions which deserve much greater attention from researchers. 


\section{CONCLUSIONS}

When telephones were first placed in factories, it was expected that the managers would use them to call their workers in order to direct their activities. The shock that occurred when the first worker called the employer must have been significant. Schools now have to face up to similar culture shock issues about the educational use of computers. They must make a philosophical decision about the nature and purpose of public education - who is it for and for what purpose? I would argue strongly that the focus must be on providing the individual with the ability to learn outside of the formal education system, and to develop appropriate skills with which to actively engage in knowledge construction. There is so much evidence about the increase in our knowledge base, and its rate of change, that we should accept that to adopt essentially transmissive curriculum models is irresponsible. We need to find ways in which we can help our students to become masters of, not slaves to, this knowledge base. The school curriculum should be the first place that we start with this major task.

Although the comments in the previous section were confined to Papert's constructionist model, similar concerns have been raised in other contexts, for example science education. There is a fundamental problem that schools face in adopting a humanistic-constructivist curriculum model; it overturns the institutional structure and focus. Institutional inertia and the industrial realities of the teaching profession will ensure that schools do not become the educational shop-fronts advocated by Ivan Illich in the 1970's. It is almost certain that they will retain most of their present characteristics for many years.

In attempting to address these and other "quality" issues in the informatics curriculum, it is clear that a humanistic curriculum has much to offer, putting real knowledge and learning in the hands of individuals. The fundamental, challenging question we have to address is, how can we help schools to adopt such an approach in times when economic models of education are becoming more prevalent? Is a set of "guidelines for good practice" adequate? Do we have to document and publicise exemplary practice? Should we ensure that research findings are more widely published and addressed to the school community? Do we need to write educational monographs for teachers and teacher-training, and should this be a focus? Is "constructivism" a suitable theme for a conference? IFIP WG 3.1 has a broadly based membership which should be able to address, at least in part, all of these issues.. 
92 Integrating information technology into education

\section{REFERENCES}

1. Papert, S. (1987) A Critique of Technocentrism in Thinking About the School of the Future. Children in an Information Age: Opportunities for Creativity, Innovation and new Activities. Sofia, Bulgaria.

2. Abelson, H. and P. Goldenberg, (1976) Student Science Training Program in Mathematics, Physics and Computer Science. Final Report to the National Science Foundation. Massachusetts Institute of Technology.

3. Allenbrand E. (1979) Course Goals in Computer Education, K-12 Tri-County Goal Development Project, P.O. Box 8723, Portland, OR 97208: Report Number 617.

4. Barta, B., et al. (1990) Computers in the Israeli Educational System Implementation Aspects (1984-1989). in McDougall, A. and Dowling, C (eds) Computers in Education Sydney, Australia: Elsevier Science Publishers.

5. Bosler, U. (1990) New Information Technology at the Secondary Level: A Survey of the Situation in the Federal Republic of Germany. in McDougall, A. and Dowling, C (eds) Computers in Education Sydney, Australia: Elsevier Science Publishers.

6. Driver, R. and E. Scanlon (1989) Computer Experience, Self-Concept and Problem-Solving: The Effects of LOGO on Children's Ideas of Themselves as Learners. Journal of Educational Computing Research, 1989. 5 (2) 199-212.

7. James, C.B. (1989) Observations on Electronic Networks: Appropriate Activities for Learning. Computing Teacher, 16 (8) 17-19.

8. Qi, C. and W. Ben-Zhong. (1990) Educational Computing in Chinese Schools. in McDougall, A. and Dowling, C (eds) Computers in Education Sydney, Australia: Elsevier Science Publishers.

9. Feldmann, B. (1993) Human-Centered Science in Education and Technology. in Rethinking the Roles of Technology in Education. Cambridge, Massachusetts: The University of Texas at Austin.

10. Papert, S. (1993). The Children's Machine., New York: Basic Books.

11. Dertouzos, M.L. (1989) Made in America. Cambridge, Massachusetts: The MIT Press.

12. Naisbitt, J. (1984) Megatrends. London: MacDonald \& Co. 
13. Levin, J.A. et. al, (1989) Technology's Role in Restructuring Schools. Electronic Learning, 8 (8) 8-9.

14. Bigum, C. (1994) Schooling in an age of informed cynicism. Deakin University: Faculty of Education.

15. Halla, M. (1990) The Electronic School District Project: Wide Area Networking for Primary and Secondary Education.in McDougall, A. and Dowling, C (eds) Computers in Education Sydney, Australia: Elsevier Science Publishers.

16. Hawkridge, D. (1990). Computer's in Third World Secondary Schools: The Ministry's Viewpoint. in McDougall, A. and Dowling, C (eds) Computers in Education Sydney, Australia: Elsevier Science Publishers.

17. Leventhall, S., P. Stevens, and M. Melton. (1993) Managing Data Daemons. in Rethinking the Roles of Technology in Education. Cambridge, Massachusetts: The University of Texas at Austin.

18. Papert, S. (1980) Mind Storms. New York: Basic Books.

19. Harel, I. and Papert, S. (1993) Constructionism. Norwood, New Jersey: Ablex.

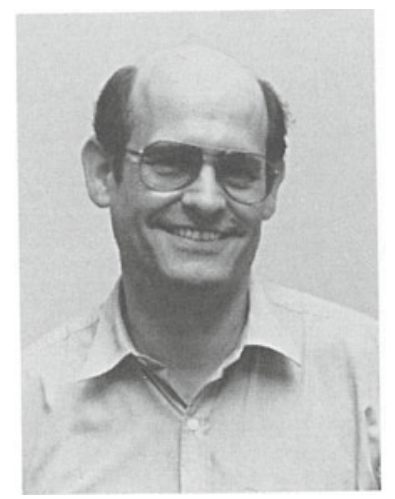

Paul Nicholson studied science at post-graduate level and then taught science and computing in schools, completing his M Ed in 1984. Since 1988 he has co-ordinated post-graduate computer education courses at Deakin University. He is undertaking a $\mathrm{PhD}$ in the use of computer-based probes for studying cognition. Paul is the author of several books on physics education, "sysop" of a FIDO bulletin board and conducts training courses in developing multi-media software, instructional design and electronic communications. His research interests are in the study of meta-cognition, the design of multi-media software and the use of telecommunications in education. 